\title{
Effects comparation of different mulching methods on soil in pitaya orchards**
}

\author{
Juan Luo ${ }^{1,2}$, Min Xu ${ }^{1}$, Chengli Liu ${ }^{1}$, Shuangshuang Wei $i^{3}$, and Hua Tang ${ }^{1 *}$ \\ ${ }^{1}$ Hainan Key Laboratory for Sustainable Utilization of Tropical Bioresources, College of Tropical Crops, Hainan University, \\ No. 58 Renmin Avenue, Haikou 570228, Hainan, P. R. China \\ ${ }^{2}$ University of Sanya, No. 191 Yingbin Avenue Xueyuan Road, Sanya 572000, Hainan, P. R. China \\ ${ }^{3}$ College of Life Science, Hainan University, No. 58 Renmin Avenue, Haikou 570228, Hainan, P. R. China
}

Received May 22, 2021; accepted October 4, 2021

\begin{abstract}
The aim of this study is to evaluate the effects of different mulching treatments, and to serve as a theoretical foundation for mulching practices in pitaya orchards of Hainan, China. In this study, the physicochemical properties, enzyme activity and also the structure and abundance of the soil microbial community were examined after a year's treatment. The results show that black fabric mulch and nature grass mulch significantly improved the soil water content, whereas its $\mathrm{pH}$ value was significantly reduced by purslane (Portulaca oleracea L.) mulch and black fabric mulch as compared to the control. Nature grass mulch increased soil organic carbon to a greater extent than control, coconut chaff mulch and also nature grass mulch significantly increased the content of alkaline hydrolysis nitrogen, nature grass mulch and black fabric mulch increased the content of available potassium more significantly than purslane (Portulaca oleracea L.) mulch and control. Treatments of nature grass mulch and purslane (Portulaca oleracea L.) mulch increased the activities of soil enzymes in the soil. The abundance of bacteria was highest in nature grass mulch and purslane (Portulaca oleracea L.) mulch, and the four mulch treatments helped to increase the richness of soil fungi more than control. The results show that all these types of mulch improved the characteristics of the soil compared with control, and nature grass mulch provided the best edaphic environment for pitaya orchards.

Keywords: mulching treatment, pitaya orchards, microbial community diversity, physicochemical characteristics of soil, Hainan province
\end{abstract}

\footnotetext{
*Corresponding author e-mail: thtiger@163.com

**This work was supported by Hainan Provincial Natural Science Foundation high-level Talents Project (320RC487, 2020-2022), the Construction of World First Class Discipline of Hainan University (RZZX201904, 2019-2021), the Species and Varieties Resources Protection Project of the Ministry of Agriculture and Rural Affairs of China (18200032-1, 2020-2021 Germplasm Protection of Pitaya).
}

\section{INTRODUCTION}

Hainan province is one of the major producers of tropical fruits in China, and the pitaya industry is a pillar of the local economy. To mitigate the effects of extreme temperature, damaging sunlight, and the soil erosion during the growth of pitaya, an increasing number of local growers are using mulch in local orchards.

The types of mulch used in this area can be broadly classified into three groups: plastic film, organic material, and living mulch. Different mulching practices have varying effects on the physicochemical and biological properties of the soil. A large body of research has shown that mulching can increase the moisture content of shallow soil by reducing evaporation and regulating its temperature (Adamaviciene et al., 2012; Ma et al., 2018). Mulching treatments are also beneficial for controlling weeds, enhancing the content of soil nutrients, improving soil enzyme activities, and improving the microecological environment (Xun et al., 2015).

While the conditions of the soil change according to the different mulching practices used, Chen et al. (2014) have claimed that although organic mulch is not mixed into soil, decomposed organic materials can be gradually absorbed into it. A relatively independent microecological system has been constructed by using film mulching which is more effective than organic mulching in terms of inhibiting evaporation and preserving heat in the soil (Zhang et al., 2010). A study by Fang et al. (2011) showed that fresh biomass can

(C) 2021 Institute of Agrophysics, Polish Academy of Sciences 
significantly improve the availability of nitrogen in the soil, and the supply of soil nutrients can be affected by the qualities of the mulching material. Living mulch can improve soil moisture by reducing evaporation (Unger and Vigil 1998), and can also improve the soil organic carbon (SOC) content (Xun et al., 2015) by enhancing microbial activity (Yao et al., 2005), which can help to decompose litter or mowed plants (Sanchez et al., 2003). The particular effects of mulching treatments on microbial communities in the soil have also been researched (Dong et al., 2017). Recent studies have shown that microorganisms in the soil can be directly influenced by mulching treatments or changes in the soil conditions (Chao et al., 2016; Chen et al., 2014) .

The effects of mulching treatments vary significantly in different environments and climates, comparative studies have determined that due to its higher temperature and the effects of a higher precipitation rate, and also, a lower cation exchange capacity (CEC), the turnover of soil $\mathrm{C}$ in tropical soils is twice as rapid as it is in temperate soils ( $\mathrm{Six}$ et al., 2002). Also, mulching treatments can accelerate the loss of organic matter from the soil, thus further degrading it (Bot et al., 2003). However, at present, there is a lack of research concerning orchard mulching with a focus on tropical regions, this is particularly the case in China. In our previous study, we compared two nearby pitaya orchards in Hainan province, the results show that black fabric cloth can lead to better fertilizer utilization efficiency, also, the abundance and diversity of fungi was higher when black fabric cloth was applied as compared with living mulch but the opposite occurred in the case of bacteria species, they were more abundant with the application of living mulch (Luo et al., 2019). The objective of this study is to examine and compare the effects of four types of mulch: black fabric mulch (BFM), coconut chaff mulch (CCM), nature grass mulch (NGM), and purslane (Portulaca oleracea L.) mulch (PO) on the physical and chemical characteristics, enzyme activities, and the diversity and abundance of the microbial community of the soil. The aim of this research is to provide a scientific basis for choosing suitable types of mulch in Hainan province.

\section{MATERIALS AND METHODS}

Field studies were carried out at the Wanzhong experimental orchard base in the town of Jianfeng (108 $46^{\prime}$ E, $18^{\circ} 40^{\prime} \mathrm{N}$ ) in Hainan in southern China, which has a tropical ocean monsoon climate. The average annual air temperature was $25.5^{\circ} \mathrm{C}$ and the mean annual precipitation was $1347.5 \mathrm{~mm}$, with more than $90 \%$ of it occurring from May to October. The average annual duration of sunshine was $2534 \mathrm{~h}$. The soil at the experiment site was savanna soil. The pitaya trees in this orchard were planted in 2012 without mulching treatment and periodically weeded through the application of a herbicide. The pitaya cultivar chosen was Dahong, and the trees were planted with a spacing of $1.5 \times 1.8 \mathrm{~m}$.

In July 2017, five treatments (Table 1) were set up and sustained as follows: 1) control (CK), 2) black fabric mulch (BFM), 3) coconut chaff mulch (CCM), 4) nature grass mulch (NGM), 5) purslane (Portulaca oleracea $\mathrm{L}$.) mulch (PO). A random block design of the five treatments was arranged, wherein each treatment was applied to three randomly arranged plots with each occupying an area of $100 \mathrm{~m}^{2}(10 \times 10 \mathrm{~m})$ and these plots were separated by 1.5 $\mathrm{m}$ buffer strips.

Previous studies have shown that the properties of soil may be determined in order to compare the effects of different mulching treatments under the same conditions over the course of a year (Qu et al., 2019). A one-year study period was also applied in this experiment, the experimental period commenced in July 2017 and ended in August 2018. During this period, 5:3:2 NPK was applied each month to achieve plant growth at a rate of $200 \mathrm{~kg} \mathrm{~N} \mathrm{ha}^{-1}$, and the watering practices and other management measures were consistent with those used by local farmers (maintaining the soil moisture content within 50-80\%).

Table 1. Experimental design of different mulching management

\begin{tabular}{cl}
\hline $\begin{array}{c}\text { Mulching } \\
\text { management }\end{array}$ & Treatment method \\
\hline CK & $\begin{array}{l}\text { Herbicide was applied to control weeds without mulching (glyphosate was applied at the recommended } \\
\text { rate of } 1125 \mathrm{~g} \mathrm{ha}^{-1} \text { in July } 2017, \text { it was subsequently sprayed on new weeds at a small-scale every half } \\
\text { month to a month). }\end{array}$ \\
Only black fabric mulch was applied. \\
CCM & $\begin{array}{l}\text { 1.5 cm layer of coconut chaff mulch was applied. } \\
\text { NGM }\end{array}$ \\
and were mowed once a month. The plants were spread out under trees after each instance of mowing. \\
Purslane (Portulaca oleracea L.) was planted around the plots which were $80 \%$ carpeted with grass one \\
year later.
\end{tabular}


The soils were sampled under the five mulching treatments (CK, BFM, CCM, NGM and PO) in August, 2018. For each plot, five samples were randomly collected from the topsoil $(0-15 \mathrm{~cm})$ and inter-row areas which avoided the issue of border interferences, these samples were mixed to form one sample. The samples were placed in sterilized plastic bags. Each one was passed through a $2 \mathrm{~mm}$ sieve to remove crop residues, pebbles, and other foreign materials, and was divided into two subsamples. The first set of subsamples were air-dried and immediately stored at $4^{\circ} \mathrm{C}$ for chemical and enzyme analysis. The second set of subsamples were stored at $-80^{\circ} \mathrm{C}$ for DNA extraction. Five samples from each plot were collected to determine the bulk density and moisture content of the soil.

The $\mathrm{pH}$ of the soil was measured with a glass electrode using a soil to water ratio of $2.5: 1$. The bulk density of the soil was determined as the mass of oven-dried soil, and fresh soil was dried in an oven at $105^{\circ} \mathrm{C}$ for $24 \mathrm{~h}$ to determine the moisture content.

Alkaline hydrolysis nitrogen (AN), and the available phosphorus (AP) and potassium (AK) were measuredusing alkaline hydrolysis diffusion, the Bray II method, and a flow auto-analyser, respectively (Zhang and Gong, 2012). The SOC was measured using the $\mathrm{K}_{2} \mathrm{CrO}_{7}-\mathrm{H}_{2} \mathrm{SO}_{4}$ oxidation method (Zhang and Gong, 2012). The activities of enzymes in the soil were measured following the procedure proposed by Wu et al. (2013), urease activity was determined using the indophenols blue method, catalase activity was determined using UV spectrophotometry, acid phosphatase activity was measured using a method described by Tabatabai and Bremner (1969), and invertase activity was measured by titration, Guan et al. (1986). All of the above parameters were determined with 3 duplicates.

Soil DNA was extracted from a $0.5 \mathrm{~g}$ sample of composite fresh soil using PowerSoil ${ }^{\mathrm{TM}}$ DNA Isolation Kits (Qiagen) which were used according to the manufacturer's protocol, and the quantity and quality of the DNA were determined using a NanoDrop ${ }^{\mathrm{TM}} 2000$ spectrophotometer (Thermo Scientific, USA).

A quantitative PCR (qPCR) system was used to determine the copy numbers of the $16 \mathrm{~S}$ and $18 \mathrm{~S}$ genes in the samples. The forward primer $341 \mathrm{~F}$ (5'-CCTACGGGAGGCAGCAG-3') and reverse primer 534R (5'-ATTACCGCGGCTGCTTGG-3') were used to target the 16S rRNA(Vasileiadis et al., 2012), and the forward primer ITS1-f (5'-TCCGTAGGTGAACCTGCGC-3') and reverse primer 5.8S (5'-TCCTCCGCTTATTGATATGC-3') were used to target the ITS genes (Ciric et al., 2010).

An ABI 7000 (PE Applied Biosystems) real-time PCR machine was used to conduct the qPCR test. Each reaction was performed in a $20 \mu \mathrm{L}$ mixture containing $0.3 \mu \mathrm{L}$ of each primer $(0.4 \mathrm{mM}), 12.5 \mu \mathrm{L}$ of SYBR Premix Ex Taq $^{\text {TM }}$ (Takara, Dalian, China), $0.3 \mu \mathrm{L}$ of ROX dye, $1 \mu \mathrm{L}$ of template DNA, and $5.6 \mu \mathrm{L}$ of double-distilled water. Each reaction was duplicated and contained negative sam- ples (free from DNA) in order to monitor the sample for potential contamination. The thermal profile was $95^{\circ} \mathrm{C}$ for $5 \mathrm{~min}$ followed by 35 cycles at $95^{\circ} \mathrm{C}$ for $15 \mathrm{~s}, 55^{\circ} \mathrm{C}$ for $30 \mathrm{~s}, 72^{\circ} \mathrm{C}$ for $1.5 \mathrm{~min}$, and a plate-reading step at $80.5^{\circ} \mathrm{C}$ for $30 \mathrm{~s}$. In order to calculate amplification specificity, a melting curve analysis was performed to confirm product specificity. The gene fragments of bacterial (V3-V4 region of the 16S rRNA genes) and fungal (ITS2 region of the $18 \mathrm{~S}$ rRNA genes) origin were PCR-amplified and cloned into the pGEM-T Easy Vector. The clones that had the appropriate gene inserts were chosen as the standards for qPCR. Ten-fold serial dilutions of a known copy number of plasmid DNA with the appropriate gene inserts were generated to produce a standard curve, respectively. The bacterial and fungal copy number were expressed in terms of per gram of soil (fresh weight), the relative values were log-transformed and the $\mathrm{R}^{2}$ value were $>99 \%$.

The V3-V4 region of the 16S rRNA genes was amplified by PCR according to the bacterial primers 341F (5'-CCTACGGGNGGCWGCAG-3') and 805R (5'-GACTACHVGGGTATCTAATCC-3'), and the ITS2 region of the $18 \mathrm{~S}$ rRNA genes was amplified using the fungal primerBITS (5'-ACCTGCGGARGGATCA-3') and reverse primer B58S3 (5'-GAGATCCRTTGYTRAAAGTT-3') (Bokulich and Mills, 2013).

A $25 \mu \mathrm{L}$ PCR reaction featuring $1 \mu \mathrm{L}$ of the template DNA, $15 \mu \mathrm{L}$ of $2 \times$ Taq PCR MasterMix (Aidlab), $0.5 \mu \mathrm{L}$ of forward and reverse primers ( $5 \mu \mathrm{m}$ of each primer), and $8 \mu \mathrm{L}$ of double-distilled water was performed for every sample. The PCR conditions were as follows: $94^{\circ} \mathrm{C}$ for $45 \mathrm{~s}, 30$ cycles of $95^{\circ} \mathrm{C}$ for $30 \mathrm{~s}, 54^{\circ} \mathrm{C}$ for $30 \mathrm{~s}$, and $72^{\circ} \mathrm{C}$ for $30 \mathrm{~s}$, followed by $5 \mathrm{~min}$ at $72^{\circ} \mathrm{C}$. The products of PCR were extracted and purified after amplification. The amplicons were then quantified and pooled at equal concentrations, and diluted to create one sample. Sequencing was performed using the Illumina Hiseq PE250 platform at the Personal Biotechnology Co., Ltd. Shanghai, China.

The bacterial and fungal sequencing data, with the adaptor and primer sequences removed, and a unique barcode assigned to each sample were analysed by the Quantitative Insights into Microbial Ecology (QIIME) software package (version 1.7.0). The sequences covered the V3-V4 region of the bacterial 16S rRNA genes, and the ITS2 region of the fungal $18 \mathrm{~S}$ rRNA genes were clustered into operational taxonomic units (OTUs) at a confidence threshold of $97 \%$ by using UPARSE software (version 7.1, http://drive5.com/uparse/) (Edgar 2013). The OTUs after this were used to annotate taxonomic information. Finally, the sequences in this study were sent to the Sequence Read Archive (SRA) database of the NCBI under accession number PRJNA574235 for the bacteria and fungi.

Alpha diversity (Chao1, ACE, Shannon, and species' diversity) was calculated using QIIME (version 1.7.0). The taxonomies of the 16S rRNA gene sequence and 18S rRNA sequence were analysed using the Ribosomal Database 
Project (RDP) classifier for each sample. The IBM SPSS 19.0 software and Excel 2010 were used to perform a statistical analysis. Significant differences in the characteristics of the soil, the activities of the enzymes in it, and OTU abundance (at $\mathrm{p}<0.05$ ) were among the treatments that were assessed using an ANOVA with Duncan's multiple range test. The correlation between the characteristics of the soil, the activities of the enzymes in it and the soil samples subjected to different treatments were determined by redundancy analysis (RDA) using CANOCO 5.1 software (Etten, 2005) .

\section{RESULTS}

The influence of mulch application on the physical and chemical characteristics of the soil are shown in Table 2. The soil moisture content was the lowest for CK (7.93\%) and the highest for BFM $(9.84 \%)$. The bulk density of the soil was highest for BFM, followed by $\mathrm{CK}$ and CCM, and had its lowest value for PO. The $\mathrm{pH}$ of the soil for PO was significantly lower than it was for CK, CCM, and NGM $(\mathrm{p}<0.05)$.

The results show that the content of soil nutrients were higher for NGM than for CK, and the available nutrients were higher for BFM and CCM than for CK. The different mulching modules improved the soil nutrient content to varying degrees. The SOC values of samples treated with NGM were higher than those for $\mathrm{CK}$, and the differences between BFM, CCM, and PO were not significant $(p>0.05)$. The contents of soil AN in CCM and NGM were significantly higher than it was in BFM $(p<0.05)$. The AP content was higher in NGM than in CCM and CK. AK content was higher in BFM and NGM than in PO and CK.

The soil catalase activities in NGM were higher than in PO, BFM and CK (Table 3). The acid phosphates and invertase activities of soil were higher in NGM than in the other treatments, to a significant extent. Acid phosphate activities were the lowest in CK and BFM as compared to other treatments. The soil urease activities were higher in NGM, PO and CCM than in CK and BFM $(p<0.05)$.

There were no significant differences in bacterial OTUs, while the number of fungal OTUs in PO was lower than in other treatments $(p<0.05)$ (Table 4). The coverage of these treatments ranged from 95.13 to $96.19 \%$ for bacteria, and from 99.75 to $99.84 \%$ for fungi.

Alpha diversity analysis was used to examine the abundance and diversity of the microbial communities in the soil (Table 4). For bacteria, the ACE index was higher for $\mathrm{PO}$ than for CK. There was no prominent difference in the Chaol index between the various treatments. The Shannon index was significantly higher for all four mulch treatments than it was for CK $(p<0.05)$. The results show that the mulch treatments helped to increase the degree of diversity and richness of bacteria in the soil compared to CK. For fungi, the ACE index and the Chaol index were lower for PO than for other treatments.

And the Shannon index was lower for PO than for BFM, CCM and NGM $(p<0.05)$.

Table 2. Physicochemical analysis of soil subjected to different mulch treatments

\begin{tabular}{|c|c|c|c|c|c|c|c|}
\hline \multirow{2}{*}{$\begin{array}{l}\text { Mulching } \\
\text { management }\end{array}$} & \multirow{2}{*}{$\mathrm{SOC}\left(\mathrm{g} \mathrm{kg}^{-1}\right)$} & $\mathrm{AN}$ & $\mathrm{AP}$ & & \multirow{2}{*}{$\begin{array}{c}\text { Moisture } \\
\text { content }(\%)\end{array}$} & \multirow{2}{*}{$\begin{array}{l}\text { Bulk density } \\
\quad\left(\mathrm{g} \mathrm{cm}^{-3}\right)\end{array}$} & \multirow{2}{*}{$\mathrm{pH}\left(\mathrm{H}_{2} \mathrm{O}\right)$} \\
\hline & & & $\left(\mathrm{mg} \mathrm{kg}^{-1}\right)$ & & & & \\
\hline $\mathrm{CK}$ & $17.43 \pm 1.25 b$ & $33.97 \pm 1.29 \mathrm{c}$ & $13.52 \pm 0.46 \mathrm{c}$ & $161.33 \pm 2.62 \mathrm{c}$ & $7.93 \pm 0.85 \mathrm{c}$ & $1.36 \pm 0.02 b$ & $5.94 \pm 0.05 \mathrm{a}$ \\
\hline BFM & $18.08 \pm 1.11 \mathrm{ab}$ & $39.69 \pm 2.25 b$ & $19.05 \pm 0.24 \mathrm{ab}$ & $206.33 \pm 5.51 \mathrm{a}$ & $9.84 \pm 0.36 \mathrm{a}$ & $1.49 \pm 0.03 \mathrm{a}$ & $5.47 \pm 0.20 b c$ \\
\hline $\mathrm{CCM}$ & $19.14 \pm 0.87 \mathrm{ab}$ & $51.07 \pm 3.40 \mathrm{a}$ & $17.46 \pm 0.68 b$ & $190.33 \pm 9.29 \mathrm{ab}$ & $9.00 \pm 0.19 \mathrm{ab}$ & $1.37 \pm 0.03 b$ & $5.90 \pm 0.16 \mathrm{a}$ \\
\hline NGM & $20.62 \pm 1.12 \mathrm{a}$ & $48.29 \pm 1.35 \mathrm{a}$ & $20.11 \pm 0.87 \mathrm{a}$ & $202.33 \pm 10.79 a$ & $9.15 \pm 0.20 \mathrm{ab}$ & $1.32 \pm 0.04 \mathrm{bc}$ & $5.81 \pm 0.02 \mathrm{ab}$ \\
\hline PO & $18.09 \pm 1.48 \mathrm{ab}$ & $37.19 \pm 1.55 \mathrm{c}$ & $18.97 \pm 0.85 \mathrm{ab}$ & $176.00 \pm 3.61 b c$ & $8.03 \pm 0.29 b c$ & $1.27 \pm 0.01 \mathrm{c}$ & $5.25 \pm 0.12 \mathrm{c}$ \\
\hline
\end{tabular}

CK - control, BFM - black fabric mulch, CCM - coconut chaff mulch, NGM - nature grass mulch, PO - purslane (Portulaca oleracea L.) mulch. Mean \pm standard error.

Table 3. Catalase, acid phosphates, urease and invertase activities in samples subjected to different mulch treatments

\begin{tabular}{lcccc}
\hline \multirow{2}{*}{$\begin{array}{l}\text { Mulching } \\
\text { management }\end{array}$} & Catalase activity & Acid phosphate activity & Urease activity & Invertase activity \\
\cline { 2 - 5 } & \multicolumn{3}{c}{$\left(\mathrm{U} \mathrm{g} \mathrm{g}^{-1}\right)$} \\
\hline CK & $1.05 \pm 0.06 \mathrm{c}$ & $0.87 \pm 0.08 \mathrm{~d}$ & $10.37 \pm 0.64 \mathrm{~b}$ & $37.13 \pm 0.62 \mathrm{~cd}$ \\
BFM & $0.65 \pm 0.04 \mathrm{c}$ & $1.01 \pm 0.02 \mathrm{~d}$ & $9.43 \pm 0.61 \mathrm{~b}$ & $35.34 \pm 4.44 \mathrm{~d}$ \\
$\mathrm{CCM}$ & $2.08 \pm 0.13 \mathrm{ab}$ & $1.55 \pm 0.04 \mathrm{c}$ & $12.83 \pm 0.87 \mathrm{a}$ & $42.54 \pm 0.39 \mathrm{bc}$ \\
NGM & $2.71 \pm 0.15 \mathrm{a}$ & $2.61 \pm 0.02 \mathrm{a}$ & $13.70 \pm 0.46 \mathrm{a}$ & $57.25 \pm 0.35 \mathrm{a}$ \\
PO & $1.36 \pm 0.59 \mathrm{bc}$ & $2.27 \pm 0.14 \mathrm{~b}$ & $13.63 \pm 0.72 \mathrm{a}$ & $47.93 \pm 1.12 \mathrm{~b}$ \\
\hline
\end{tabular}

Mean \pm standard error, values followed by different letters differ significantly (Duncan's test, $\mathrm{p}<0.05$ ). Other explanations as in Table 2. 
Table 4. Alpha diversity measures of bacteria and fungi in samples subjected to different mulch treatments

\begin{tabular}{|c|c|c|c|c|c|}
\hline Mulching management & Coverage $(\%)^{*}$ & OTUs & $\mathrm{ACE}$ & Chaol & Shannon \\
\hline \multicolumn{6}{|c|}{ Bacteria } \\
\hline CK & $96.19 \pm 0.31$ & $6058 \pm 169 a$ & $8716 \pm 83 b$ & $8559 \pm 100 \mathrm{a}$ & $10.42 \pm 0.02 b$ \\
\hline BFM & $95.15 \pm 0.76$ & $6235 \pm 673 a$ & $9281 \pm 775 \mathrm{ab}$ & $9065 \pm 827 \mathrm{a}$ & $10.70 \pm 0.06 \mathrm{a}$ \\
\hline CCM & $95.31 \pm 0.74$ & $6146 \pm 308 \mathrm{a}$ & $9107 \pm 199 \mathrm{ab}$ & $9019 \pm 249 a$ & $10.65 \pm 0.02 \mathrm{a}$ \\
\hline NGM & $95.63 \pm 0.24$ & $6075 \pm 68 \mathrm{a}$ & $9044 \pm 66 \mathrm{ab}$ & $8879 \pm 81 \mathrm{a}$ & $10.66 \pm 0.05 \mathrm{a}$ \\
\hline $\mathrm{PO}$ & $95.13 \pm 0.84$ & $6842 \pm 648 \mathrm{a}$ & $10080 \pm 659 a$ & $9846 \pm 673 a$ & $10.74 \pm 0.06 \mathrm{a}$ \\
\hline \multicolumn{6}{|c|}{ Fungi } \\
\hline $\mathrm{CK}$ & $99.84 \pm 0.01 \mathrm{a}$ & $2334 \pm 188 \mathrm{a}$ & $3304 \pm 207 a$ & $3226 \pm 198 \mathrm{a}$ & $6.82 \pm 0.85 \mathrm{ab}$ \\
\hline BFM & $99.76 \pm 0.00 \mathrm{~b}$ & $1993 \pm 131 \mathrm{a}$ & $2726 \pm 242 b$ & $2717 \pm 250 \mathrm{a}$ & $6.92 \pm 0.22 \mathrm{a}$ \\
\hline $\mathrm{CCM}$ & $99.80 \pm 0.02 \mathrm{ab}$ & $2152 \pm 150 \mathrm{a}$ & $3019 \pm 194 \mathrm{ab}$ & $2941 \pm 171 \mathrm{a}$ & $7.19 \pm 0.03 \mathrm{a}$ \\
\hline NGM & $99.81 \pm 0.01 \mathrm{ab}$ & $2247 \pm 115 \mathrm{a}$ & $3163 \pm 167 \mathrm{ab}$ & $3095 \pm 187 \mathrm{a}$ & $7.06 \pm 0.08 \mathrm{a}$ \\
\hline $\mathrm{PO}$ & $99.75 \pm 0.06 \mathrm{~b}$ & $1112 \pm 190 \mathrm{~b}$ & $1470 \pm 225 \mathrm{c}$ & $1520 \pm 203 b$ & $5.72 \pm 0.38 b$ \\
\hline
\end{tabular}

Mean \pm standard error. Values followed by different letters differ significantly (Duncan's test, $\mathrm{p}<0.05$ ). *For library coverage of samples. Other explanations as in Table 2.

The relative abundance of the bacterial and fungal communities at the phylum level are shown in Fig. 1. For bacteria, the first 10 phyla are shown, the most dominant phyla were Proteobacteria and Actinobacteria, accounting for more than $45 \%$ in all five treatments. The relative abundance of Proteobacteria was 37.7, 36.6, 37, 38.2 and $31.7 \%$ for BFM, CCM, NGM, PO and CK. Actinobacteria were found to be at a level of $18.9 \%$ in CK, and were 17.6, $15.1,14.5$ and $11.7 \%$ in NGM, PO, CCM and BFM, respectively. The third most abundant phylum $(10 \%$ relative abundance on average) was Acidobacteria. This phylum was the most abundant one in samples treated with CCM (11.1\%) followed by CK (10.7\%), BFM (9.9\%), NGM (9.6\%), and PO (8.6\%). The next most abundant phyla were Gemmatimonadetes, Planctomycetes, and Chloroflexi, the relative abundance of each of these was greater than 5\%.

For fungi, Ascomycota was the dominant phylum across all soil treatments. Basidiomycota and Mortierellomycota only accounted for a minor part of the total. The relative abundance of Basidiomycota ranged from 2.0 to $4.0 \%$. The relative abundance of Mortierellomycota was 3.5\% in BFM.

The bacterial and fungal abundance was quantified using $\mathrm{qPCR}$, and the results show a significant difference between samples subjected to different mulch treatments. Bacterial abundance ranged from $0.48 \times 10^{6}$ to $1.82 \times 10^{6}$ copy numbers/g of fresh soil (Fig. 2a). The decreasing order of treatments in terms of the copy numbers of the $16 \mathrm{~S}$ rRNA gene is NGM $>\mathrm{PO}>\mathrm{CCM}>\mathrm{BFM}>\mathrm{CK}$. The bacterial abundance in samples subjected to NGM and PO was $1.82 \times 10^{6}$ and $1.59 \times 10^{6}$ copy numbers/g fresh soil, respectively, it was significantly higher than those of other treatments $(p<0.05)$. For fungi, the average abundance ranged from $0.12 \times 10^{6}$ to $1.57 \times 10^{6}$ copy numbers $/ g$ of fresh soil for different mulch treatments (Fig. 2b). The sequence of abundance of 18S rRNA from the highest to lowest was $\mathrm{NGM}>\mathrm{PO}>\mathrm{CCM}>\mathrm{BFM}>\mathrm{CK}$. Samples subjected to NGM had the largest fungi population, it was 13.08 times higher than that of CK.

Redundancy analysis (RDA) was used to analyse the relationships between the various characteristics of the soil, and the bacteria and fungi in it with different treatments (Fig. 3). For bacteria, the first and second components explained 64.03 and $24.28 \%$ of the total variation in orders, respectively. The CK treatments were separated from all of the other treatments in case of bacterial data. The activities of catalase, invertase, urease, and phosphate demonstrated close correlations between the bacterial community. The bulk density of the soil and its water content were predominantly associated with $\mathrm{CCM}$ and BFM, and also, the $\mathrm{pH}$ value was positively correlated with CK (Fig. 3a).

For fungi, the first axis of the RDA explains $93.54 \%$ of the total variation. Urease, invertase, and phosphates were positively correlated with $\mathrm{PO}$, and catalase was positively correlated with CCM. The bulk density of the soil, the moisture content, and AK showed close correlations with BFM. The three samples subjected to CK were separated from one another in the fungal data (Fig. 3b).

\section{DISCUSSION}

The four mulching treatments (BFM, CCM, NGM, and PO) had various influences on the physical and chemical properties of the soil. For example, the moisture and bulk density of the soil were highest in BFM, which is consistent with past work (Liu et al., 2014a). Previous studies reported that black plastic film mulch is more efficient than organic mulch at reducing the rate of evaporation (Zhao et al., 2019). This might be why the bulk density of soil was significantly higher for BFM than for other mulch treatments. 
(A)

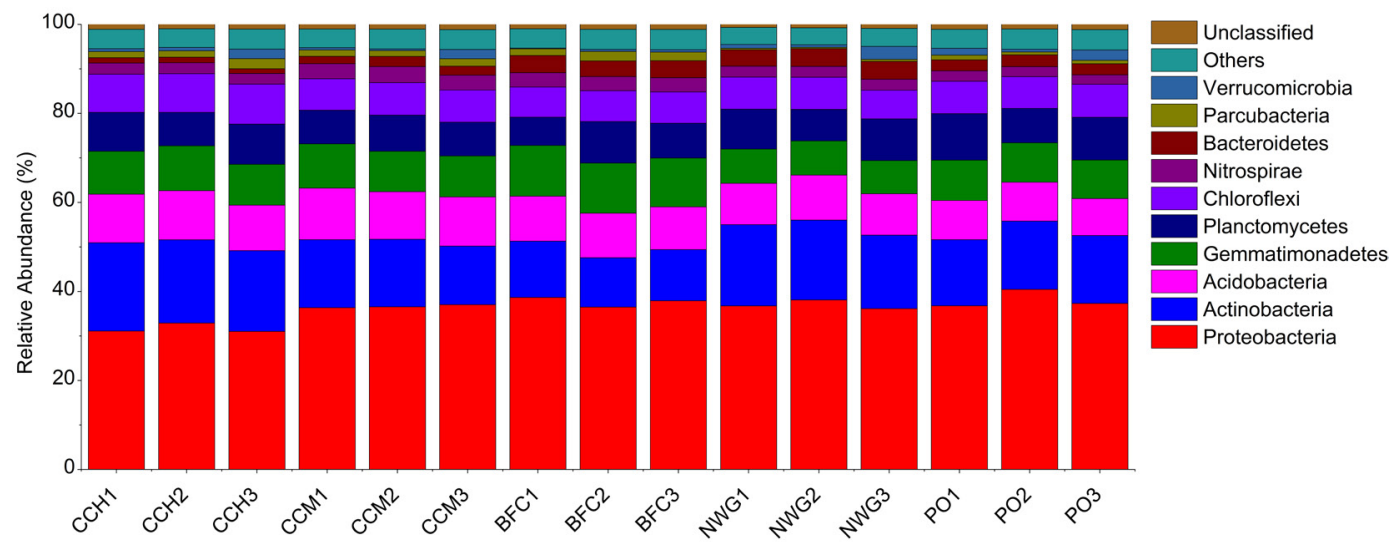

(B)

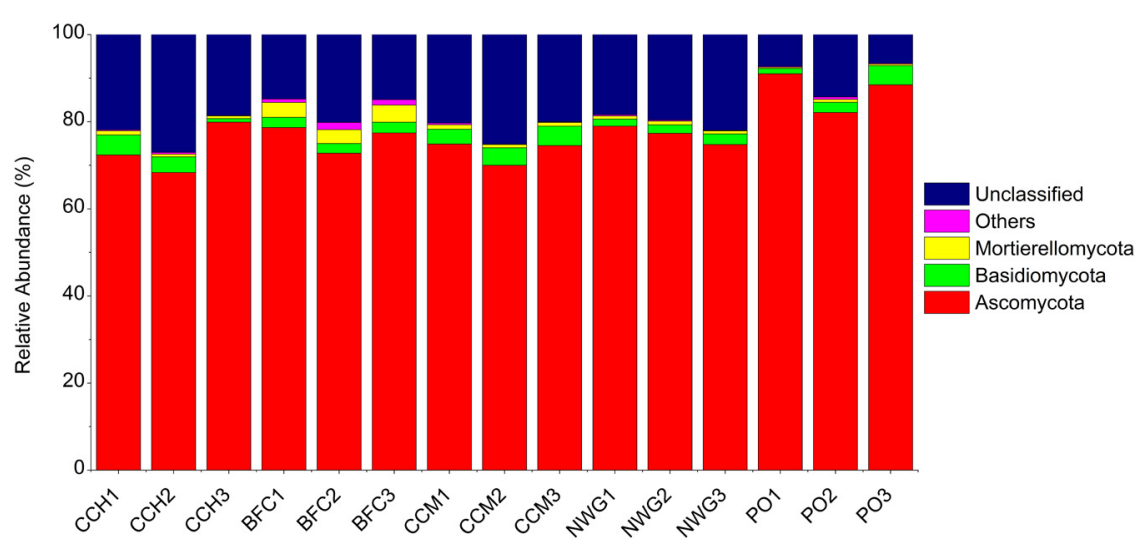

Fig. 1. Relative abundance of bacterial (A) and fungal (B) phyla in soil subjected to different mulch treatments. CK - control, BFM black fabric mulch, CCM - coconut chaff mulch, NGM - nature grass mulch, PO - purslane (Portulaca oleracea L.) mulch.

a

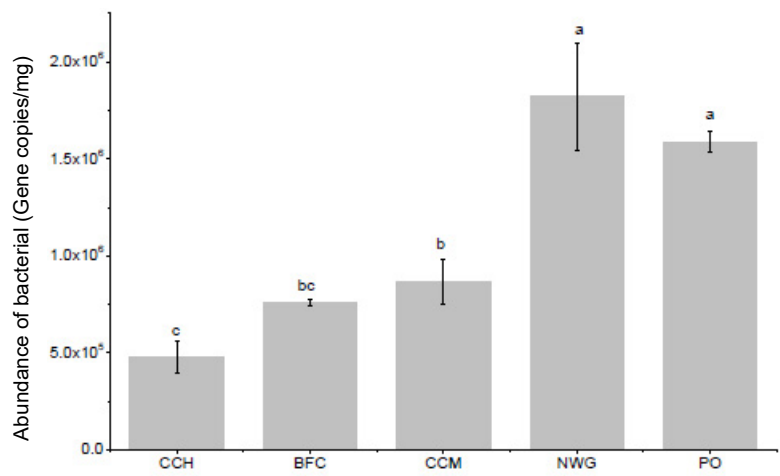

b

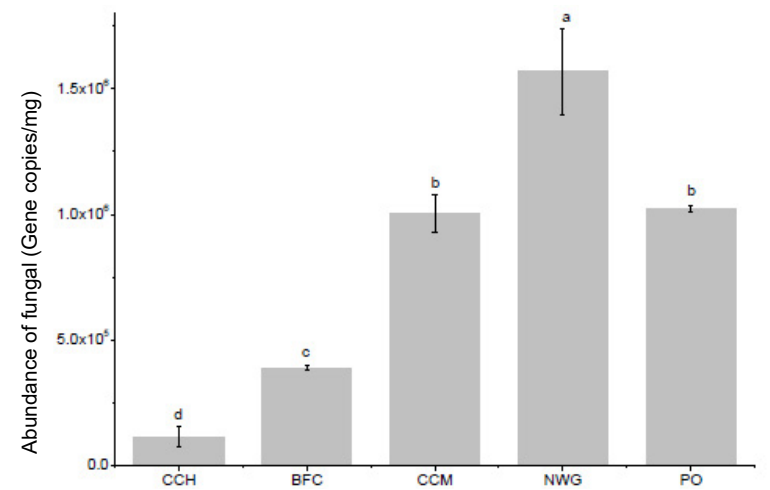

Fig. 2. Abundance of bacteria (a) and fungi (b) in the soils of the pitaya orchard under different mulching patterns. CK - control, BFM: black fabric mulch, CCM - coconut chaff mulch, NGM - nature grass mulch, PO - purslane (Portulaca oleracea L.) mulch. Values followed by different letters differ significantly (Duncan's test, $\mathrm{p}<0.05$ ). Bars represent standard errors.

The SOC content was lower for CK than for NGM. Other studies found that SOC is not significantly higher for BFM than for CK (Ma et al., 2018; Luo et al., 2019), which is consistent with the results of this study. Previous research has also shown that the long-term application of a film of mulch reduces the SOC content of soil (Xiaobo et al., 2018), this is possibly due to increased mineralization (Xiao-Gang and Feng-Min, 2015). Cadavid et al. (1998) have reported that organic mulch can significantly benefit by increasing the SOC, but in our research, CCM did not have a significant effect on SOC, possibly because of the short mulching period. Each type of mulch except for PO significantly improved the availability of soil nutrients. Qu et al. (2019) have also shown that different mulch treatments have similar effects concerning the improvement the available nutrients in soil. The contents of SOC and available nutrients in NGM were higher than those of CK. However, in the case of SOC, AN and AK there was no clear increase in $\mathrm{PO}$ compared with $\mathrm{CK}$, which indicates that naturally occurring grass and purslane (Portulaca oleracea $\mathrm{L}$.) yielded different results in terms of the contents of nutrients in the soil. Zhong et al. (2018) also reported that 

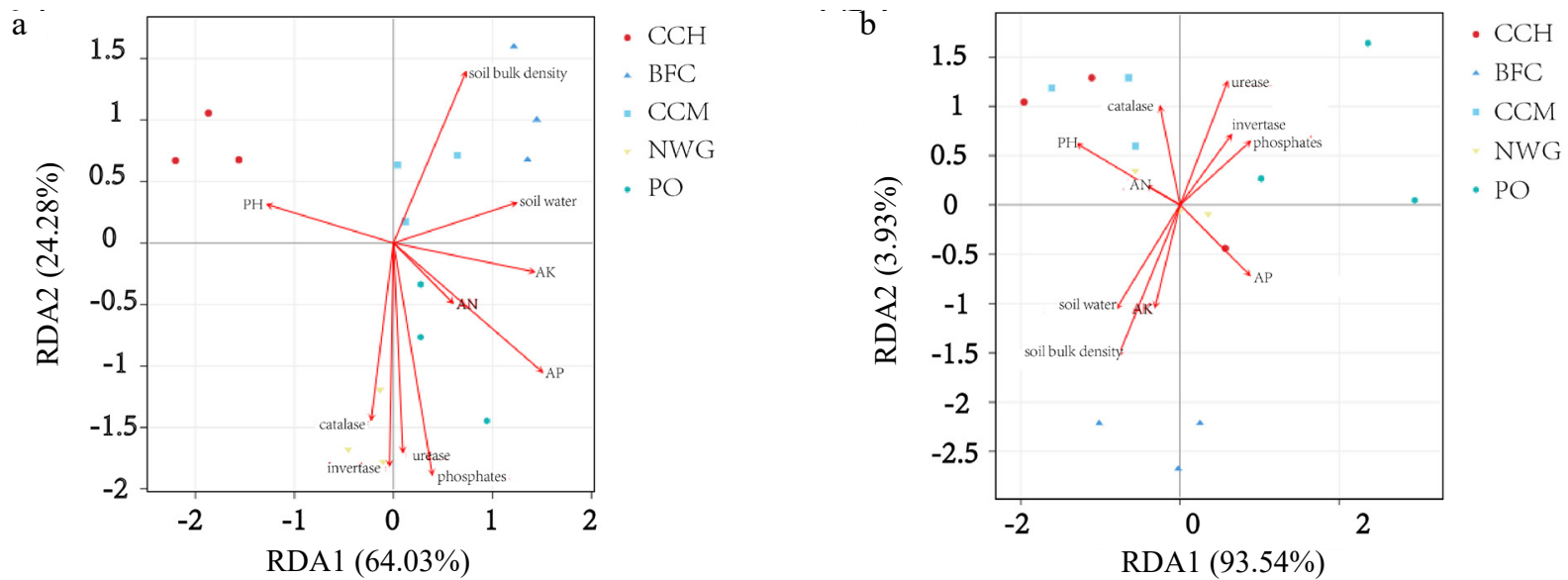

Fig. 3. Redundancy analysis (RDA) of the compositions of bacterial (a) and fungal (b) communities, and their environmental variables with different mulch treatments. CK - control, BFM - black fabric mulch, CCM - coconut chaff mulch, NGM- nature grass mulch, PO - purslane (Portulaca oleracea L.) mulch.

the effects of improving the soil nutrients vary between the living mulch species. A study concerning living mulch has shown that mulch plants can increase the content of nutrients in the soil by improving its microbial activity (Yao et al., 2005) and producing root exudates (Hoagland et al., 2008). However, in another way, mulch plants can reduce nutrients in soil by absorbing them (Xun et al., 2015). In this study, the available nutrient contents were higher for NGM than for PO, which shows that grass types have an obvious influence on the availability of nutrients in the soil (Zhong et al., 2018).

The activity of soil enzymes is the key factor influencing biochemical processes in the soil (Xiaobo et al., 2018), and can make a contribution to maintaining or even increasing soil fertility (Burns et al., 2013). For example, urease and acid phosphatase in the soil have been shown to be related to such nutrients as those involved in the mineralization of $\mathrm{N}, \mathrm{P}$, and K (Haroun, 2010). Other studies have shown that the activities of enzymes in the soil are enhanced in rooted soil by the plant-mediated activation of microorganisms (Cheng et al., 2005). Different types of grass have different effects concerning the enhancement of the activity of soil enzymes. For example, studies have shown that leguminous mulch can improve soil enzyme activity more efficiently than Gramineae mulch (Adamaviciene et al., 2012). Caravaca et al. (2005) found that the values of hydrolases were highest in $H$. portulacoides rhizosphere soil. In this research, NGM contributed more significantly to improving soil enzyme activity than PO, which also shows that the relationship between the species of grass applied to the soil and the enzyme activity was significant. The activities of enzymes in CCM was significantly higher than that in CK. Some scholars claim that mulching treatments can improve the moisture content of the soil by reducing the rate of evaporation (A'Bear et al., 2014). There was no difference in the enzyme activities of catalase, urease, and invertase between BFM and CK, the tropical heat probably had the same effect in both cases.

The related experiments show that mulching types affect both microbial abundance and composition (Wei et al., 2018b), and microorganisms in the soil can enhance the cycling of nutrients and improve their storage prospects (Shibahara et al., 1998). In our research, the diversity and richness of soil bacteria were higher in all mulch-treated samples, as found in previous studies (MeiyanWu et al., 2009). Jin et al. (2009) have suggested that the microbial population is related to the influence of mulch on the physical and chemical characteristics of the soil. In the case of fungi, NGM had a higher richness than other treatments, Schirmel et al. (2018) demonstrated that the activities of soil microbes is significantly higher in organically mulched fields than in fields with plastic mulch. Pan et al. (2016) found that organic mulch helps to promote the microbial biomass of soil and increase the proportion of fungi. The improvement in the conditions of soil are important in terms of improving the abundance and diversity of the microorganisms within it (Mbah et al., 2014). The improvement in certain characteristics of its physical-chemical structure, such as the organic matter content, nutrient availability, moisture status, and porosity in organic mulches, helps to improve the growth of microorganisms (Abdullah, 2014). Some research suggests that inefficient nutrient cycling in plastic mulch can reduce the level of soil microbial activity (Schirmel et al., 2018). Numerous studies have shown that the litter properties of plant species are essential to the structure and activity of the soil microbial community (Bardgett, 2007). While PO produced the lowest value of fungal diversity, previous studies have shown that differences in bacterial and fungal diversity in soil may be explained through the variation in plant residues and the input of exudates between plant species (Legay et al., 2014). Previous studies have also suggested that 
Actinobacteria and Acidobacteria show a clear preference for growing in nutrient-poor soil (Zhang et al., 2016). The phyla of these two bacteria were dominant in our research, which is consistent with the results of past studies (Chao et al., 2016). Wang et al. (2019) concluded that a decrease in soil nutrient content can stimulate an increase in the number of branches of Proteobacteria and Actinobacteria. The Actinobacteria, which can decompose recalcitrant organic carbon (Dang et al., 2017), are spore-forming bacteria that dominate in harsh and stressful soil conditions. It has been established that Acidobacteria tend to be more proficient with regard to soil $\mathrm{C}$ transformation and the metabolization of recalcitrant organic substrates $(\mathrm{Li}$ et al., 2017), also, some subgroups of Acidobacteria have been observed to be abundant in soil with a higher SOC content (Liu et al., 2014b). Other research has concluded that Acidobacteria are more abundant oligotrophic organisms in carbon-poor soils (Wang et al., 2019; Noah et al., 2007) also found that Acidobacteria were relatively less abundant in resource-rich plots than in no-litter plots, which may be explained by the copiotrophic/oligotrophic model of community effects on decomposition. It was found that the fungal diversity of soil was directly related to its properties (such as its physical-chemical characteristics) (Yang et al., 2017). Ascomycota was the dominant phylum of all samples subjected to treatment in this research, and is also the dominant fungal community in the majority of ecosystems worldwide (Menkis et al., 2015). Many taxa belonging to Ascomycota are associated with the decomposers of organic matter (Urbina et al., 2016), and also, organic mulch might facilitate the growth of this phylum. The properties of the plants growing in the soil have an indirect effect on fungal diversity (Yang et al., 2017), indeed several studies have suggested that fast-growing plant species that produce large amounts of litter and root exudates are more effective than slow-growing species in terms of enhancing fungal diversity (Kembel et al., 2012). The relationship between the microorganism community in the soil and its physicochemical conditions remains unclear (Wei et al., 2018a). Our study indicates shifting patterns in the structure and community of the microbial biomass under different mulch treatments.

\section{CONCLUSIONS}

1. The soil water content for black fabric mulch was significantly higher than it was for purslane (Portulaca oleracea L.) mulch and control, whereas the bulk density increased due to the application of black fabric mulch. purslane (Portulaca oleracea L.) mulch was favourable due to the decrease in soil bulk density.

2. Different mulching modules improved the soil nutrient content to varying degrees. Soil nutrients such as soil organic carbon, alkaline hydrolysis nitrogen, available potassium and available phosphorus were higher for nature grass mulch than for control.
3. Coconut chaff mulch, nature grass mulch and purslane (Portulaca oleracea L.) mulch were helped to improve the activities of urease and acid phosphate. The invertase activity was highest for nature grass mulch as compared to the other treatments.

4. Moreover, mulch treatments can help to improve the abundance of bacteria and fungi. The changes in the bacterial and fungal communities were correlated with the physicochemical properties of the soil, which might be affected by mulching practices.

5. A long-term assessment of the soil environment is required to obtain a clear understanding of different mulching practices.

Conflict of interest: The authors declare no conflict of interest.

\section{REFERENCES}

A'Bear A.D., Jones T.H., Kandeler E., and Boddy L., 2014. Interactive effects of temperature and soil moisture on fungal-mediated wood decomposition and extracellular enzyme activity. Soil Biol. Biochem., 70, 151-158.

https://doi.org/10.1016/j.soilbio.2013.12.017

Abdullah A.S., 2014. Minimum tillage and residue management increase soil water content, soil organic matter and canola seed yield and seed oil content in the semiarid areas of Northern Iraq. Soil Till. Res., 144, 150-155.

https://doi.org/10.1016/j.still.2014.07.017

Adamaviciene A., Romaneckas K., Pilipavicius V., Avizienyte D., Sarauskis E., and Sakalauskas A., 2012. Interaction of maize and living mulch: Soil chemical properties and bioactivity. J. Food Agric. Environ., 10, 1219-1223.

Bardgett R.D., 2010. The biology of soil: a community and ecosystem approach. Soil Use Management (Eds M.J.Crawley, C. Little, T.R.E. Southwood, and S. Ulfstrand). Oxford University Press, UK.

Bokulich N.A. and Mills D.A., 2013. Improved selection of internal transcribed spacer-specific primers enables quantitative, ultra-high-throughput profiling of fungal communities. Appl. Environ. Microbiol., 79, 2519-2526. https://doi.org/10.1128/AEM.03870-12

Bot A.J., Amado U.C., Mielniczuk J., and Benites J., 2003. Conservation agriculture as a tool to reduce emission of greenhouse gasses. A case from Southern Brazil. Conservation Agriculture: Environment, Farmers Experiences, Innovations, Socio-Economy, Policy. https://doi.org/10.1007/978-94-017-1143-2_50

Burns R.G. et al., 2013. Soil enzymes in a changing environment: Current knowledge and future directions. Soil Biol. Biochem., 58, 216-234. https://doi.org/10.1016/j.soilbio.2012.11.009

Cadavid L.F., El-Sharkawy M.A., Acosta A., and Sánchez T., 1998. Long-term effects of mulch, fertilization and tillage on cassava grown in sandy soils in northern Colombia. Field Crops Res., 57, 45-56. https://doi.org/10.1016/S0378-4290(97)00114-7 
Caravaca F., Aiguacil M.M., Torres P., and Roldan A., 2005. Plant type mediates rhizospheric microbial activities and soil aggregation in a semiarid Mediterranean salt marsh. Geoderma, 124, 375-382. https://doi.org/10.1016/j.geoderma.2004.05.010

Chao Z., Liu G., Sha X., and Wang G., 2016. Soil bacterial community dynamics reflect changes in plant community and soil properties during the secondary succession of abandoned farmland in the Loess Plateau. Soil Biol. Biochem., 97, 40-49. https://doi.org/10.1016/j.soilbio.2016.02.013

Chen Y., Wen X., Sun Y., Zhang J., Wei W., and Liao Y., 2014. Mulching practices altered soil bacterial community structure and improved orchard productivity and apple quality after five growing seasons. Scientia Hort., 172, 248-257. https://doi.org/10.1016/j.scienta.2014.04.010

Cheng W.X., Kuzyakov Y., Zobel R.W., and Wright S.F., 2005. Root Effects on Soil Organic Matter Decomposition (Eds S. Wright, R. Zobel). Roots and soil management: interactions between roots and the soil. agronomy monograph No. 48 . ASA, Madison: 119-143.

Ciric L., Pratten J., Wilson M., and Spratt D., 2010. Development of a novel multi-triplex qPCR method for the assessment of bacterial community structure in oral populations. Environ. Microbiol. Reports, 2, 770-774. https://doi.org/10.1111/j.1758-2229.2010.00183.x

Dang P., Yu X., Le H., Liu J., Shen Z., and Zhao Z., 2017. Effects of stand age and soil properties on soil bacterial and fungal community composition in Chinese pine plantations on the Loess Plateau. Plos One, 12(10): e0186501 https://doi.org/10.1371/journal.pone.0186501

Dong W., Si P., Liu E., Yan C., Zhang Z., and Zhang Y., 2017. Influence of film mulching on soil microbial community in a rainfed region of northeastern China. Scientific Reports, 7, https://doi.org/10.1038/s41598-017-08575-w

Edgar R.C., 2013. UPARSE: highly accurate OTU sequences from microbial amplicon reads. Nature Methods, 10, 9961000. https://doi.org/10.1038/nmeth.2604

Etten E.V., 2005. Multivariate Analysis of Ecological Data using CANOCO. Bulletin of the Ecological Society of America, 86, 6-6. https://doi.org/10.1890/0012-9623(2005)86[6a: MAOEDU]2.0.CO;2

Fang S., Xie B., Liu D., and Liu J., 2011. Effects of mulching materials on nitrogen mineralization, nitrogen availability and poplar growth on degraded agricultural soil. New Forests, 41, 147-162. https://doi.org/10.1007/s11056-010-9217-9

Guan S.Y., Zhang D., and Zhang Z., 1986. Soil enzyme and its research methods (in Chinese) (Ed. Q.H. Chen). Agriculture Press, Beijing, China.

Haroun M., 2010. Effect of composting on sludge contaminated with heavy metals from three different tannery streams and their bioavailability to plants. Int. J. Environ. Eng., 2, 429446. https://doi.org/10.1504/IJEE.2010.035459

Hoagland L., Carpenter-Boggs L., Granatstein D., Mazzola M., Smith J., Peryea F., and Reganold J.P., 2008. Orchard floor management effects on nitrogen fertility and soil biological activity in a newly established organic apple orchard. Biol. Fertil. Soils, 45, 11.

https://doi.org/10.1007/s00374-008-0304-4
Jin K., Sleutel S., Buchan D., Neve S.D., Cai D.X., Gabriels D., and Jin J.Y., 2009. Changes of soil enzyme activities under different tillage practices in the Chinese Loess Plateau. Soil Till. Res., 104, 115-120. https://doi.org/10.1016/j.still.2009.02.004

Kembel S.W. et al., 2012. Architectural design influences the diversity and structure of the built environment microbiome. Isme J., 6, 1469-1479.

https://doi.org/10.1038/ismej.2011.211

Legay N. et al., 2014. Contribution of above- and below-ground plant traits to the structure and function of grassland soil microbial communities. Ann. Bot., 114, 1011-1021. https://doi.org/10.1093/aob/mcu169

Li F., Chen L., Zhang J., Yin J., and Huang S., 2017. Bacterial community structure after long-term organic and inorganic fertilization reveals important associations between soil nutrients and specific taxa involved in nutrient transformations. Frontiers Microbiol., 8, 187. https://doi.org/10.3389/fmicb.2017.00187

Liu J., Bu L., Lin Z., Luo S., Chen X., and Li S., 2014a. Optimizing plant density and plastic film mulch to increase maize productivity and water-use efficiency in semiarid areas. Agronomy J., 106, 1138-1146. https://doi.org/10.2134/agronj13.0582

Liu J. et al., 2014b. High throughput sequencing analysis of biogeographical distribution of bacterial communities in the black soils of northeast China. Soil Biol. Biochem., 70, 113-122. https://doi.org/10.1016/j.soilbio.2013.12.014

Luo J. et al., 2019. Differential responses of the soil microbial community in two pitaya orchards with different mulch types. Scientific Reports, 9, 10413. https://doi.org/10.1038/s41598-019-46920-3

Ma D., Lei C., Qu H., Wang Y., Misselbrook T., and Rui J., 2018. Impacts of plastic film mulching on crop yields, soil water, nitrate, and organic carbon in Northwestern China: A metaanalysis. Agric. Water Manag., 202, 166-173. https://doi.org/10.1016/j.agwat.2018.02.001

Mbah C.N., Nwite J.N., Njoku C., Ibeh L.M., and Igwe T.S., 2014. Physical properties of an ultisol under plastic film and no-mulches and their effect on the yield of maize. World J. Agric. Sci., 6, 160-165.

Meiyan Wu, Lianghuan Wu, Limei Zhao, and Meimei Chen, 2009. Effects of continuous plastic film mulching on paddy soil bacterial diversity. Acta Agric. Scandinavica, 59, 286-294.

https://doi.org/10.1080/09064710802095024

Menkis A., Marciulynas A., Gedminas A., Lynikiene J., and Povilaitiene A., 2015. High-Throughput sequencing reveals drastic changes in fungal communities in the phyllosphere of Norway spruce (Picea abies) following invasion of the spruce bud scale (Physokermes piceae). Microbial Ecol., 70, 904-911. https://doi.org/10.1007/s00248-015-0638-z

Noah F., Bradford M.A., and Jackson R.B., 2007. Toward an ecological classification of soil bacteria. Ecology, 88, 13541364. https://doi.org/10.1890/05-1839 
Pan F., Li Y., Chapman S.J., and Yao H., 2016. Effect of rice straw application on microbial community and activity in paddy soil under different water status. Environ. Sci. Poll. Res., 23, 5941-5948. https://doi.org/10.1007/s11356-015-5832-5

Qu B. et al., 2019. Effect of various mulches on soil physicochemical properties and tree growth (Sophora japonica) in urban tree pits. Plos One, 14: e0210777. https://doi.org/10.1371/journal.pone.0210777

Sanchez J.E. et al., 2003. Orchard floor and nitrogen management influences soil and water quality and tart cherry yields. J. Am. Soc. Hort. Sci., 128, 277-284. https://doi.org/10.21273/JASHS.128.2.0277

Schirmel J., Albert J., Kurtz M.P., and Munoz K., 2018. Plasticulture changes soil invertebrate assemblages of strawberry fields and decreases diversity and soil microbial activity. Appl. Soil Ecol., 124, 379-393. https://doi.org/10.1016/j.apsoil.2017.11.025

Shibahara F., Yamamuro S., and Inubushi K., 1998. Dynamics of microbial biomass nitrogen as influenced by organic matter application in paddy fields. Soil Sci. Plant Nutr., 44, 167-178. https://doi.org/10.1080/00380768.1998.10414437

Six J., Feller C., Denef K., Ogle S.M., Sa J.C.D., and Albrecht A., 2002. Soil organic matter, biota and aggregation in temperate and tropical soils - Effects of no-tillage. Agronomie, 22, 755-775. https://doi.org/10.1051/agro:2002043

Tabatabai M.A. and Bremner J.M., 1969. Use of p-nitrophenyl phosphate for assay of soil phosphatase activity. Soil Biol. Biochem., 1, 301-307. https://doi.org/10.1016/0038-0717(69)90012-1

Unger P.W. and Vigil M.F., 1998. Cover crop effects on soil water relationships. J. Soil Water Conserv., 53, 200-207.

Urbina H., Scofield D.G., Cafaro M., and Rosling A., 2016. DNA-metabarcoding uncovers the diversity of soil-inhabiting fungi in the tropical island of Puerto Rico. Mycoscience, 57, 217-227. https://doi.org/10.1016/j.myc.2016.02.001

Vasileiadis S., Puglisi E., Arena M., Cappa F., Cocconcelli P.S., and Trevisan M., 2012. Soil bacterial diversity screening using single $16 \mathrm{~S}$ rRNA gene $\mathrm{V}$ regions coupled with multimillion read generating sequencing technologies. Plos One, 7: e42671. https://doi.org/10.1371/journal.pone.0042671

Wang K. et al., 2019. Effects of grassland afforestation on structure and function of soil bacterial and fungal communities. Sci. Total Environ., 676, 396-406. https://doi.org/10.1016/j.scitotenv.2019.04.259

Wei Z., Gong Q., Zhao Z., Jie L., Zhai B., Wang Z., and Li Z., 2018a. Changes in the soil bacterial community structure and enzyme activities after intercrop mulch with cover crop for eight years in an orchard. Eur. J. Soil Biol., 86, 34-41. https://doi.org/10.1016/j.ejsobi.2018.01.009
Wei Z., Zhao Z., Gong Q., Zhai B., and Li Z., 2018b. Effects of cover crop in an apple orchard on microbial community composition, networks, and potential genes involved with degradation of crop residues in soil. Biol. Fertility Soils, 54, 743-759. https://doi.org/10.1007/s00374-018-1298-1

Wu D., Wang Y., Hu S., and Wang N., 2013. Remediation of Soil with $\mathrm{Cd}, \mathrm{Zn}, \mathrm{Pb}$ combined pollution by chlorophytum comosum growth. J. Soil Sci., 44, 1245-1252.

Xiao-Gang L. and Feng-Min L., 2015. Soil organic carbon balance and nitrogen cycling in plastic film mulched croplands in rainfed farming systems. Scientia Agric. Sinica, 48, 4630-4638.

Xiaobo G. Yuannong L., and Yadan D., 2018. Film-mulched continuous ridge-furrow planting improves soil temperature,nutrient content and enzymatic activity in a winter oilseed rape field, Northwest China. J. Arid Land, 10, 362374. https://doi.org/10.1007/s40333-018-0055-5

Xun Q., Jie G, Pan H.J., Zhang K.Y., Wei S., Wang X.J., and Hua G., 2015. Effects of living mulches on the soil nutrient contents, enzyme activities, and bacterial community diversities of apple orchard soils. Eur. J. Soil Biol., 70, 23-30. https://doi.org/10.1016/j.ejsobi.2015.06.005

Yang Y., Dou Y., Huang Y., and An S., 2017. Links between soil fungal diversity and plant and soil properties on the loess plateau. Frontiers in Microbiol., 8, 2198.

https://doi.org/10.3389/fmicb.2017.02198

Yao S., Merwin I.A., Bird G.W., Abawi G.S., and Thies J.E., 2005. Orchard floor management practices that maintain vegetative or biomass groundcover stimulate soil microbial activity and alter soil microbial community composition. Plant Soil, 271, 377-389. https://doi.org/10.1007/s11104-004-3610-0

Zhang G. and Gong Z., 2012. Soil survey laboratory methods. Science Press, Beijing.

Zhang Y., Dong S., Gao Q., Liu S., Zhou H., Ganjurjav H., and Wang X., 2016. Climate change and human activities altered the diversity and composition of soil microbial community in alpine grasslands of the Qinghai-Tibetan Plateau. Sci. Total Environ., 562, 353-363. https://doi.org/10.1016/j.scitotenv.2016.03.221

Zhang Y., Xie Y.S., Hao M.D., and She X.Y., 2010. Effects of different patterns surface mulching on soil properties and fruit trees growth and yield in an apple orchard. Ying Yong Sheng Tai Xue Bao, 21, 279-286. 